\title{
Effect of inorganic and organic zinc supplementation on coccidial infections in goat kids
}

\author{
Petra Strnadová1, Vlasta Svobodová1, Leoš Pavlata², Lubica Mišurová2, Rudolf Dvořák \\ ${ }^{1}$ Department of Pathological Morphology and Parasitology, ${ }^{2}$ Ruminant and Swine Clinic, Faculty of Veterinary \\ Medicine, University of Veterinary and Pharmaceutical Sciences Brno, Czech Republic
}

Received September 9, 2009

Accepted October 26, 2010

\begin{abstract}
The aim of this study was to identify the effect of zinc-enriched diet fed to goats and their kids on the number of Coccidia oocysts shed by kids, on clinical signs of coccidiosis, weight gains, and kids' blood plasma concentration of zinc. A total of 22 goat kids were divided into 4 groups of 5 or 6 animals. Goats and kids from the control group did not receive any additional zinc, the second group was supplemented with inorganic zinc (zinc oxide), the third group was given zinc lactate, and the fourth group received chelated zinc. Samples of kids' faeces were taken weekly from 3 to 9 weeks of their age (a total of 7 samples were taken). Samples of faeces were examined by a quantitative method to detect the number of oocysts. Kids were weighed weekly and their blood was taken in order to determine zinc concentrations in blood plasma. Animals from the group supplemented with zinc chelate and zinc lactate shed a significantly $(p \leq 0.05)$ lower number of oocysts $(13.4 \%$ and $11.9 \%$, respectively) compared to the number of oocyst shed by control and zinc oxide supplemented groups ( $25 \%$ and $49.7 \%$, respectively). Shedding of oocysts was not accompanied by clinical symptoms of coccidiosis in any of the groups. Kids supplemented with zinc chelate showed significantly highest weight gains and blood plasma concentration of zinc $(p \leq 0.05)$ as compared to control and inorganic zinc supplemented groups. Organic zinc is to be recommended to be used as a prophylaxis against coccidiosis in goat kids.
\end{abstract}

Eimeria, coccidiosis, weight gain, zinc chelate, zinc lactate, zinc oxide

Infections caused by Eimeria coccidia belong to the most significant protozoal infections. In goat kids, six specific Eimeria species were detected, namely E. arloingi, E. ninakohlyakimovae, E. christenseni, E. hirci, E. caprina and E. alievi. Their prevalence is considered to be global. In Spain, coccidiosis affects $96.1 \%$ goat kids fed milk (Ruiz et al. 2006). In northern Jordan, coccidiosis occurs in 85\% local goats and 54\% of them show concurrent infection with multiple Eimeria species. Incidence of concurrent infection was significantly higher in kids (66\%) than in animals over 1 year of age (49\%) (Mahmoud and Hossan 2003). Prevalence of coccidia in the U.S.A. was 100\% $(\mathrm{n}=318)$; in Australia, coccidia were detected in 97\% kids out of 497 (Reeg et al. 2005). In the Czech Republic, Strnadová et al. (2008) found coccidia in 54\% kids less than 4 months old.

The course of clinical coccidiosis in goat kids can be acute, subacute, chronic or latent. The first symptoms of acute coccidiosis include raised temperature, watery diarrhea containing blood and particles of intestinal mucosa, mucosal anaemia, conjunctivitis and rhinitis. Mahmoud and Hossan (2003) reported up to 58\% mortality of kids. Animals from 1 to 3 months of age are most susceptible and they shed oocysts most intensively between 5 and 8 weeks of age (Reeg et al. 2005). The course of infection is affected by the number of oocysts being shed. Coccidiosis is considered to be clinical when more than 100,000 Eimeria oocysts are detected in $1 \mathrm{~g}$ of faeces (Scott 2007).

Interaction between the parasite and the host leading to the development of clinical infection is affected by many important factors including nutrition. Overall zinc content in the organism significantly affects the body weight of the individual (Bellof et al. 2007).

Phone: +420541562265

Fax: +420541562 266

Email: svobodovav@vfu.cz

http://www.vfu.cz/acta-vet/actavet.htm 
In animal organism, zinc works as an activator of more than 200 enzymes and that is why its deficiency has a negative impact on the organisms as a whole (Evans and Halliwell 2001). Insufficient zinc concentrations cause decreased activity of $T$ cells and thus zinc affects immunity both directly and indirectly (Shi et al. 1998). Low concentrations of zinc in blood were reported in parasitic infections (Tasci et al. 1995), as parasites utilize zinc for their metabolic and biochemical processes (Scott and Koski 2000).

Physiological range of zinc concentration in blood plasma of sheep and goats is $12.5-18 \mu \mathrm{mol} / 1$. Zinc concentration in colostrum and milk is quite high and reflects the level of intake of dietary zinc. Zinc concentrations in milk of sheep and goats range between 3 and $5 \mathrm{mg} / \mathrm{l}$, in colostrum between 15 and $25 \mathrm{mg} / \mathrm{l}$. Zinc requirement in mammals is 40 to $100 \mathrm{mg} / \mathrm{kg}$ of dietary dry matter. Youngs that grow rapidly need more zinc. Requirement of zinc in adults is increased during pregnancy and high lactation (Jelínek et al. 2003).

Natural zinc sources include bran, grains and fodder yeast. The following forms of zinc supplementation are permitted by regulatory authorities: zinc chloride, monohydrate; zinc oxide; zinc lactate, trihydrate; zinc acetate, dihydrate; zinc sulphate, monohydrate; zinc sulphate, heptahydrate; zinc carbonate; chelated zinc and amino acids; and zinc propionate.

In case of zinc deficiency, it is advisable to administer higher doses of zinc than recommended (NRC 1985). This should improve weight gains and feed conversion ratio as well as ensure higher concentrations of zinc in the organism (Sharma et al. 2004).

In the present study, the effect of zinc supplementation in kids was evaluated in relation with shedding of Eimeria oocysts, weight gain, blood zinc concentrations and clinical signs of coccidiosis in the examined animals.

\section{Materials and Methods}

In total, 22 goat kids (11 males and 11 females) were naturally infected with Eimeria oocysts and kept in stables of the Ruminant Clinic of the University of Veterinary and Pharmaceutical Sciences Brno. Kids and their mothers were randomly divided to 4 groups (A, B, C, D), each containing 5 or 6 kids. Mothers were divided in this way as early as 4 months before parturition.

Animals of the control group (A) received no additional zinc; group B was supplemented with inorganic zinc (zinc oxide) at the dose of $60 \mathrm{mg} / \mathrm{kg}$ dry matter of diet; group C received zinc lactate (zinc lactate trihydrate, Zinc Chelate, Agrobac, Czech Republic) at the dose of $60 \mathrm{mg} / \mathrm{kg}$ dry matter of diet; and group D were given zinc chelate (Bioplex Zn, Alltech, USA) at the dose of $60 \mathrm{mg} / \mathrm{kg}$ dry matter of diet. Goats received Zn-enriched diet 4 months before parturition. The diet of goats before parturition consisted of commercial pelleted feed for goats, hay ad libitum, mineral lick and zinc supplement. After parturition, mothers were given also grout and oat. In the first days, newborn kids sucked mother's milk only, but after about 7 days after the parturition, they started to eat also the diet intended for their mothers. Throughout the experiment, kids had free access to their mothers' diet.

As soon as kids reached the age of 3 weeks, samples of their faeces were taken weekly until they were 9 weeks old (altogether 7 times). Samples were obtained from kids using special pants for collection of faeces. The pants were put on in the morning and were left on kids for about $4 \mathrm{~h}$.

Mixed samples of faeces from individual groups were examined quantitatively according to McMaster, and OPG

Table 1. Semiquantitative microscopic evaluation of Eimeria oocysts in feces of goat kids

\begin{tabular}{ll}
\hline Infection intensity & \multicolumn{1}{c}{ Number of oocysts } \\
\hline Negative & 0 in the sample \\
$+/-$ & $1-2$ in some visual field \\
+ & $1-3$ in every visual field \\
++ & $4-6$ in every visual field \\
+++ & 7 and more in every visual field \\
\hline
\end{tabular}

(Oocyts Per Gram). The samples were analyzed also by a basic flotation method and the intensity of infection was evaluated semiquantitatively as demonstrated in Table 1. In total, 28 group samples of faeces were examined from March to May 2007.

The kids were weighed every week throughout the experiment, starting on the parturition day. Blood samples were taken from kids in order to identify zinc concentrations. Blood was obtained from vena jugularis and collected into disposable heparinized plastic test tubes. Within $2 \mathrm{~h}$ of sampling the blood plasma was separated from the whole blood after centrifugation. Blood samples from kids were taken on the parturition day and on day 2 and 7 after birth. Afterwards, kids were sampled every second week (on weeks 3, 5, 7 and 9).

Zinc concentrations in blood plasma were determined in the laboratory of the Ruminant Clinic by the method of flame AAS at Solaar M6 (Unicam, Great Britain) following the previous deproteination 
of sample by adding trichloracetic acid at the 1:1 ratio. Zinc was determined in the supernatant after centrifugation.

The data samples were evaluated by parametric tests, namely one-way analysis of variance using Bartlett's test. Subsequent evaluation of data was done using Tukey-Kramer method. Non-parametric Kruskal-Wallis test and Steel-Dwass test were used in case of non-homogenous variances that occurred in some data samples.

\section{Results}

In all groups supplemented with zinc (B, C, D), a slower onset of coccidiosis was observed. Kids from these groups started to shed oocysts several weeks later than kids from the control group. Kids from the control group (A) started to shed Eimeria oocysts first at 4 weeks of age. The highest number of oocysts 56650 were shed by kids from the group supplemented with inorganic zinc (group B). Kids from the group C supplemented with zinc lactate started to shed oocysts as late as in week 6 . At this time, kids from this group shed the least number of oocysts throughout the experiment, i.e. $11.9 \%$ of the total number of Eimeria oocysts shed in all groups. Animals from group D supplemented with zinc in the form of chelate started to shed oocysts in week 5 . Numbers of oocysts shed in $1 \mathrm{~g}$ of faeces of goats in individual groups during the whole experiment are summarized in Table 2.

Table 2. Number of oocysts in $1 \mathrm{~g}$ of faeces in goat kids sorted by age and groups

\begin{tabular}{ccccc}
\hline Age of kids (in weeks) & $\begin{array}{c}\text { Group A }(\mathrm{n}=6) \\
\text { Control }\end{array}$ & $\begin{array}{c}\text { Group B }(\mathrm{n}=6) \\
\text { Zn oxide }\end{array}$ & $\begin{array}{c}\text { Group C }(\mathrm{n}=5) \\
\text { Zn lactate }\end{array}$ & $\begin{array}{c}\text { Group D }(\mathrm{n}=5) \\
\text { Zn chelate }\end{array}$ \\
\hline 3 & 0 & 0 & 0 & 0 \\
4 & $100(+/-)^{*}$ & 0 & 0 & 0 \\
5 & $18650(+++)$ & 0 & 0 & $4400(++)$ \\
6 & $2500(++)$ & $6300(++)$ & $6000(++)$ & $1850(+)$ \\
7 & $1550(+)$ & $25900(+++)$ & $1350(+)$ & $350(+/-)$ \\
8 & $3000(++)$ & $17100(+++)$ & $1850(+)$ & $8250(+++)$ \\
9 & $2700(++)$ & $7350(+++)$ & $4400(++)$ & $450(+/-)$ \\
Total & 28500 & 56650 & 13600 & 15300 \\
Percentage (\%) & 25.0 & 49.7 & 11.9 & 13.4 \\
\hline
\end{tabular}

*Semiquantitative evaluation according to Table 1

Groups of kids that received organic zinc (lactate, chelate) shed significantly less Eimeria oocysts $(p \leq 0.05)$ compared to the control group and the inorganic zinc group. Throughout the experiment, kids from the inorganic group (group B) shed the most oocysts $(49.7 \%)$. On the contrary, kids from the zinc lactate and chelate groups shed the least number of oocysts $11.9(13.4 \%)$. Shedding of oocysts was not accompanied by clinical symptoms of coccidiosis (diarrhea) in any group.

Average weekly weight gains of kids, standard deviations, and numbers of animals in individual groups are summarized in Table 3. Statistical evaluation of the results indicated that in week 3, group D showed significantly higher weight gains compared to group B ( $p=$ $0.011)$. The same situation was observed in week $4(p=0.004)$. Moreover, group D showed significantly higher weight gains compared to group $\mathrm{A}(p=0.018)$ and group $\mathrm{C}(p=0.005)$. In week 5 , animals from group $\mathrm{D}$ showed again significantly higher weight gains compared to group B $(p=0.021)$ and group A $(p=0.026)$. The situation was similar in week 6 and week 8 . Kids from group D had significantly higher weight gain compared to group B ( $p=$ $0.045, p=0.011)$. In weeks $1,2,7$ and 9 , the measured values were non-significant.

Average zinc concentrations in kids' blood plasma, standard deviations and numbers of animals in individual groups are demonstrated in Table 4. The results of the present study indicate that the highest bioavailability was observed in chelated zinc. Five out of seven measurements showed that zinc concentration was highest in blood of kids receiving 
Table 3. Weekly weight gains in goat kids $(\mathrm{kg})$

\begin{tabular}{ccccc}
\hline \multirow{2}{*}{$\begin{array}{c}\text { Age of kids } \\
\text { (in weeks) }\end{array}$} & $\begin{array}{c}\text { Group A }(\mathrm{n}=6) \\
\text { Control }\end{array}$ & $\begin{array}{c}\text { Group B }(\mathrm{n}=6) \\
\text { Zn oxide }\end{array}$ & $\begin{array}{c}\text { Group C }(\mathrm{n}=5) \\
\text { Zn lactate }\end{array}$ & $\begin{array}{c}\text { Group D }(\mathrm{n}=5) \\
\text { Zn chelate }\end{array}$ \\
\cline { 2 - 5 } & $\Phi \pm \mathrm{s}$ & $\Phi \pm \mathrm{s}$ & $\Phi \pm \mathrm{s}$ & $\Phi \pm \mathrm{s}$ \\
\hline 1 & $1.45 \pm 0.12$ & $1.62 \pm 0.21$ & $1.61 \pm 0.14$ & $1.54 \pm 0.22$ \\
2 & $1.85 \pm 0.12$ & $1.74 \pm 0.48$ & $1.46 \pm 0.34$ & $1.65 \pm 0.32$ \\
4 & $1.62 \pm 0.30$ & $1.15 \pm 0.53^{\mathrm{a}}$ & $1.39 \pm 0.34$ & $2.08 \pm 0.49^{\mathrm{a}}$ \\
5 & $1.56 \pm 0.24^{\mathrm{b}}$ & $1.41 \pm 0.47^{\mathrm{a}}$ & $1.38 \pm 0.33^{\mathrm{c}}$ & $2.28 \pm 0.33^{\mathrm{abc}}$ \\
6 & $1.45 \pm 0.50^{\mathrm{b}}$ & $1.42 \pm 0.33^{\mathrm{a}}$ & $1.73 \pm 0.74$ & $2.43 \pm 0.40^{\mathrm{ab}}$ \\
7 & $1.35 \pm 0.53$ & $0.70 \pm 0.55^{\mathrm{a}}$ & $1.18 \pm 0.64$ & $1.66 \pm 0.46^{\mathrm{a}}$ \\
8 & $1.77 \pm 0.37$ & $1.50 \pm 0.91$ & $0.68 \pm 0.83$ & $1.64 \pm 0.61$ \\
9 & $1.44 \pm 0.48$ & $0.33 \pm 0.39^{\mathrm{a}}$ & $1.00 \pm 0.93$ & $1.8 \pm 0.86^{\mathrm{a}}$ \\
\hline
\end{tabular}

$\Phi$ - mean value calculated from the measured values; $s$ - standard deviation;

a:a-c:c on the line of the table - significant differences between groups $(p \leq 0.05)$

Table 4. Zinc concentrations in goat kids' blood plasma ( $\mu \mathrm{mol} / \mathrm{l})$

\begin{tabular}{ccccc}
\hline \multirow{2}{*}{ Age of kids } & $\begin{array}{c}\text { Group A }(\mathrm{n}=6) \\
\text { Control }\end{array}$ & $\begin{array}{c}\text { Group B }(\mathrm{n}=6) \\
\text { Zn oxide }\end{array}$ & $\begin{array}{c}\text { Group C }(\mathrm{n}=5) \\
\text { Zn lactate }\end{array}$ & $\begin{array}{c}\text { Group D }(\mathrm{n}=5) \\
\text { Zn chelate }\end{array}$ \\
\cline { 2 - 5 } & $\Phi \pm \mathrm{s}$ & $\Phi \pm \mathrm{s}$ & $\Phi \pm \mathrm{s}$ & $\Phi \pm \mathrm{s}$ \\
\hline Day 0 & $5.22 \pm 1.49$ & $5.24 \pm 2.01$ & $6.23 \pm 1.01$ & $6.93 \pm 2.02$ \\
Day 2 & $19.18 \pm 2.58^{\mathrm{a}}$ & $11.31 \pm 3.22^{\mathrm{a}}$ & $17.86 \pm 2.86$ & $16.64 \pm 4.87$ \\
Day 7 & $17.51 \pm 2.15^{\mathrm{a}}$ & $14.35 \pm 1.60^{\mathrm{a}}$ & $17.30 \pm 0.77$ & $16.30 \pm 2.56$ \\
Week 3 & $16.40 \pm 1.36$ & $14.03 \pm 0.99$ & $14.62 \pm 3.26$ & $16.80 \pm 2.74$ \\
Week 5 & $13.41 \pm 2.09$ & $10.61 \pm 0.74$ & $13.13 \pm 3.07$ & $13.96 \pm 1.95$ \\
Week 7 & $11.09 \pm 0.40^{\mathrm{a}}$ & $10.86 \pm 1.43^{\mathrm{b}}$ & $11.90 \pm 0.86$ & $14.18 \pm 3.14^{\mathrm{ab}}$ \\
Week 9 & $10.91 \pm 1.14^{\mathrm{a}}$ & $10.42 \pm 0.91^{\mathrm{b}}$ & $11.46 \pm 0.67$ & $12.88 \pm 1.15^{\mathrm{ab}}$ \\
\hline
\end{tabular}

$\Phi$ - mean value calculated from the measured values; $s$ - standard deviation;

a:a, b:b on the line of the table - significant differences between groups $(p \leq 0.05)$

chelate. Increased concentration of zinc in kids fed chelate was confirmed by statistical evaluation in week 7 and week 9 compared to the control group (week 7: $p=0.038$; week 9: $p=0.020$ ) and the inorganic zinc group (week 7: $p=0.024$; week 9: $p=0.004$ ). Increased blood concentrations of zinc were associated with markedly less intensive shedding of Eimeria oocysts in the zinc chelate group compared to the control group and the inorganic zinc group. On days 2 and 7, a significantly lower zinc concentration was found in kids of mothers fed inorganic zinc compared to the control group $(p=0.005, p=0.045)$.

\section{Discussion}

Impact of various forms of zinc on the number of Eimeria oocysts being shed, weight gain, and blood concentrations of zinc were compared in order to find out whether positive effects of zinc can be used for efficient prophylaxis against Eimeria, the most common protozoal parasite of gastrointestinal tract of kids.

Impact of zinc on a course of infection is connected with host immunity. Fekete and Kellems (2007) reported that zinc has both specific and nonspecific roles in the immune defence mechanism. Zinc regulates the maturation and function of immune cells. The effect of zinc on growth and immunocompetence was described by Davis et al. (2004) and the impact of zinc on reduction of growth depression in coccidiosis was studied by Khanagwal et al. (2000). 
The lowest concentration of zinc in blood plasma of kids from goats supplemented with zinc oxide was found on days 2 and 7. Based on our results, we can presume that this form of zinc is inefficiently transferred from mother's body to colostrum and milk. The influence of food supplemented with different forms of zinc (lactate, chelate, amino acidpolypeptidic complex, oxide) on the zinc concentration in blood plasma and milk of goats was studied by Pechova et al. (2009). They found that the supplementation of different form of zinc did not influence the concentration of zinc in milk, but influenced the zinc concentration in blood plasma. The efficiency of different organic and inorganic forms of zinc was almost the same.

Animals from the inorganic zinc group shed the highest number of oocysts throughout the experiment and had lower weight gains in most weeks compared to the control group. In general, the inorganic form of zinc does not significantly affect the health of kids. Groups of kids that received organic zinc shed significantly less Eimeria oocysts compared to the control group and the inorganic zinc group.

No group of kids showed the typical symptom of coccidiosis. This corresponds also with the lower number of oocysts shed by kids. Maximum number of oocysts (OPG 25,900) was observed in week 7 in kids from the inorganic zinc group (B). Clinical coccidiosis is usually associated with OPG 100,000 (Scott 2007).

Weight gain is an important indicator of subclinical coccidiosis as well. Correlation between the number of shed Eimeria oocysts and kids' weight gain was demonstrated in this study. Weight gains decreased in weeks when kids were shedding the highest numbers of oocysts. This tendency was apparent in the inorganic zinc group where weekly weight gains markedly decreased during the onset of coccidiosis in week 6, and weight gains were also lower during the period of intensive shedding of oocysts $(+++)$. This phenomenon was not observed in the group supplemented with zinc chelate. Numbers of oocysts did not reach the values observed in group B and the onset of coccidiosis in week 5 did not affect weight gains significantly. The effect of individual forms of zinc on weight gains was proved as well (Table 3). Significantly higher gains were observed in weeks 3, 4, 5, 6 and 8 in kids receiving zinc chelate compared to kids supplemented with inorganic zinc. Compared to the control group, kids from the zinc chelate group showed increased weight gains in weeks 4 and 5 .

In addition, supplementation of chelated zinc clearly increased blood concentration of $\mathrm{Zn}$, which may be important for its other functions in the organism. Buzadžić et al. (2002) reported that best bioavailability of zinc is ensured by administering zinc chelate together with peptides and amino acids. Bioavailability of zinc methionine chelate is higher by $206 \%$ compared to supplementation with zinc sulphate (Wedekind et al. 1992). Zinc administered in this form offers higher protection against free radicals compared to zinc salts (Bagchi et al. 1998).

Kids supplemented with lactate and chelate form of zinc shed the least number of Eimeria oocysts. Although kids receiving zinc lactate were the last to start to shed oocysts (and they shed the least number of them throughout the experiment), they did not show significantly higher weight gains compared to the control group and other groups, which is a primary indicator from the perspective of animal health and cost-effectiveness. It is clear from the results that although the intensity of coccidial infection was higher in the zinc chelate group compared to the lactate group, the chelate group showed the highest weekly weight gains.

Monitoring the effects of individual forms of zinc on the number of Eimeria oocysts being shed by goats, clinical signs of the disease and weight gains indicated that organic forms of zinc (namely chelated zinc) administered to mothers and their kids decrease the number of oocysts being shed and increase the kids' weight gain. The best results were achieved by using organic forms of zinc also by Wang et al. (2010). 
Organic zinc is to be recommended to be used as prophylaxis against coccidiosis of goat kids.

\section{Vliv dotace anorganického a organicky vázaného zinku na kokcidiózu kůzlat}

Cílem naší práce bylo posoudit vliv diet obohacených zinkem podávaných kozám a jejich kůzlatům na počet vylučovaných oocyst kokcidií, klinický průběh kokcidiózy, př́růstky hmotnosti a koncentraci zinku v krevní plazmě kůzlat. Celkem 22 kůzlat bylo rozděleno do 4 skupin po 5-6 zvířatech. Kozy a kủzlata z kontrolní skupiny nedostávaly žádný přídavek zinku, druhá skupina byla suplementována anorganickým zinkem (oxid zinečnatý), třetí skupina dostávala zinek ve formě laktátu a čtvrtá skupina dostávala zinek ve formě chelátu. Vzorky trusu kůzlat byly odebírány týdně od 3. do 9. týdne věku (tj. celkem 7 odběrů). Vzorky trusu kůzlat z každé skupiny byly vyšetřovány kvantitativní metodou na počet vylučovaných oocyst kokcidií. Každý týden byla kůzlata vážena a byla jim odebírána krev na stanovení hladiny zinku v krevní plasmě. Kůzlata ze skupiny dotované zinkem ve formě chelátu a laktátu vylučovala signifikantně $(p \leq 0.05)$ nižší počet oocyst kokcidií $13,4 \%$ (resp. 11,9 \% z celkového počtu vyloučených oocyst) v porovnání s kůzlaty kontrolními a dotovanými zinkem anorganickým (ta vyloučila $25 \%$, resp. 49,7 \% z celkového počtu vyloučených oocyst). V žádné ze skupin nebyly zaznamenány klinické př́iznaky kokcidiózy. Kůzlata dotovaná chelátem zinku vykazovala ve srovnání s ostatními skupinami nejvyšší váhové př́růstky a vyšší koncentraci zinku v krevní plazmě. Organicky vázaný zinek tak může být doporučen k využití v rámci prevence kokcidiózy kůzlat.

\section{Acknowledgements}

This study was supported by the Research project of the Ministry of Education, Youth and Sports of the Czech Republic No. MSM6215712403.

\section{References}

Bagchi D, Vuchetic PJ, Bagchi M, Tran MX, Krohn RL 1998: Protective effect of zinc salts on TPA-induced hepatic and brain lipid peroxidation, glutathione depletion, DNA damage and peritoneal macrophage activation in mice. Gen Pharm 30: 43-50

Bellof G, Most E, Pallauf J 2007: Concentration of cooper, iron, manganese and zinc in muscle, fat, and bone tissue of lambs of breed German Merino Landsheep in the course of growing period and different feeding intensities. J Anim Phys Anim Nutr 91: 100-108

Buzadžić B, Korač B, Lazič T, Obradovič D 2002: Effect of supplementation with Cu and Zn on antioxidant enzyme activity in the rat tissues. Food Res Inter 35: 217-220

Davis ME, Brown DC, Maxwell CV, Johnson ZB, Kegley EB, Dvorak RA 2004: Effect of phosphorylated mannans and pharmacological additions of zinc oxide on growth and immunocompetence of wealing pigs. J Anim Sci 82: 581-587

Evans P, Halliwell B 2001: Micronutrients: oxidant/antioxidant status. B J Nutr 85: 67-74

Fekete SG, Kellems RO 2007: Interrelationship of feeding with immunity and parasitic infection: a review. Vet Med Praha 52: 131-143

Jelínek P, Koudela K, Doskočil J, Illek J, Kotrbáček V, Kovár̊ů F, Kudláč E 2003: Physiology of livestock. MZLU, Brno, 409 p. (in Czech)

Khanagwal P, Ghosh JD, Mandal AB 2000: Interaction of dietary calcium and zinc with coccidiosis in relation to broiler performance. Indian J Anim Sci 70: 619-622

Mahmoud N, Hossam A 2003: Prevalence of Eimeria species among goats in northern Jordan. Small Rum Res 49: $109-113$

NRC 1985: Nutrient Requirements of Sheep. Sixth Revised Edition, National Academy Press, Washington, D.C., $99 \mathrm{p}$.

Pechova A, Misurova L, Pavlata L, Dvorak R: The influence of supplementation of different forms of zinc in goats on the zinc concentration in blood plasma and milk. Biol Trace Elem Res 132: 112-121

Reeg KJ, Gauly M, Bauer CH, Mertens CH, Zahner H 2005: Coccidial infections in housed lambs: oocyst excretion, antibody levels and genetic influences on the infection. Vet Par 127: 209-219

Ruiz A, Gonzales JF, Rodriguez E, Marti S, Molina JM 2006: Influence of climatic and management factors on Eimeria infection in goats from semi-arid zones. J Vet Med 53: 399-402

Sharma LC, Yadav PS, Mandal AB, Sunaria KR 2004: Effect of varying levels of dietary minerals on growth and nutrient utilization in lambs. AJAS 17: 46-52 
Shi HN, Scott ME, Stevenson MM, Kosgi KG 1998: Energy restriction and zinc deficiency impair the functions of murine T cells and antigen-presenting cells during gastrointestinal nematode infection. J Nutr 128: 20-27 Scott PR 2007: Sheep Medicine. Manson Publishing, London, 336 p.

Scott ME, Koski KG 2000: Zinc deficiency impairs immune responses against parasitic nematode infections at intestinal and systemic sites. J Nutr 130: 1412-1420

Strnadová P, Svobodová V, Vernerová E 2008: Protozoal infections in lambs and kids from farms in the Czech Republic. Veterinářství 58: 451-454 (in Czech)

Tasci S, Sengil AZ, Altindis M, Arisoy K 1995: The effect of zinc supplementation in experimentally induced Toxoplasma gondii infection. J Egypt Soc Parasitol 25: 745-755

Wang Y, Tang JW, Ma WQ, Feng J, Feng J 2010: Dietary zinc glycine chelate on growth performance, tissue mineral concentrations, and serum enzyme activity in wealing piglets. Biol Trace Elem Res 133: 325-334

Wedekind KJ, Hortin AE, Baker DH 1992: Methodology for assessing zinc bioavailability: efficiency estimates for zinc methionine, zinc sulfate and zinc oxide. J Anim Sci 70: 178-184 